\title{
Genetisk psykiatrisk epidemiologi: Litt om historie og metode og noen eksempler fra angst- og depresjonsstudier
}

\author{
Kristian Tambs \\ Divisjon for epidemiologi, Nasjonalt folkehelseinstitutt, Postboks 4404 Nydalen, 0403 Oslo
}

\section{HISTORISK UTVIKLING AV METODER}

Likhet mellom slektninger ble for alvor gjenstand for vitenskapelig oppmerksomhet etter at Darwins og Mendels teorier og oppdagelser ble kjent på siste delen av forrige århundre. Noe senere rettet Freud og psykoanalysen søkelyset mot betydningen av barndomsopplevelser for individets utvikling. Rundt 1920 fikk så den ekstreme behaviorismen med John Watson en sterk posisjon innen psykologien. Et hovedbudskap var at alle individuelle forskjeller i atferd skyldtes læring, og at genetiske forskjeller derfor var uinteressante.

Darwins fetter, Sir Francis Galton, hadde alt i 1875 gjennomført den første systematiske observasjonen av tvillingpar som viste at arven har betydning for individuelle egenskaper (1). Først 50 år senere skjøt imidlertid empirisk forskning omkring dette spørsmålet fart, kanskje nettopp som følge av de skarpe motsetningene mellom noen av tidens viktigste vitenskapelige strømninger i synet på arv og miljø. Den første tvillingundersøkelsen med et design slik vi kjenner det i dag, der eneggede og toeggede sammenliknes for å finne relativ effekt av arv og miljø, ble gjennomført på begynnelsen av 20-tallet (2). De to første adoptivstudiene var amerikanske, begge undersøkte arvelighet og intelligens, og begge ble publisert i $1928(3,4)$.

Den første tvillingundersøkelsen av psykopatologi, nærmere bestemt schizofreni, som antakelig holder mål etter nyere krav til representativitet og validitet, ble gjennomført på midten av 30-tallet (5). Den første psykiatriske adoptivstudien, også av schizofreni, kom først på 60-tallet (6). Siden slutten av 60-tallet har tvilling- og adoptivstudier blitt stadig vanligere. I tillegg til schizofreni ble ulike affektive lidelser og angstlidelser gjenstand for slike undersøkelser. Etter hvert gjorde elektronisk databehandling det lettere å gjennomføre undersøkelser av relativt store utvalg. Fra midten av 70-tallet til i dag har datarevolusjonen muliggjort utvikling av kompliserte statistiske metoder som utnytter datainformasjonen fra ulike typer slektninger langt bedre enn tidligere, og som tillater at helt nye spørsmål kan besvares. Disse metodene ble riktignok tatt i bruk nokså sent i psykiatriske studier.

En tradisjon som har vært med å forme atferdsgenetikken er forskning omkring avl av planter og husdyr. Kunnskapen på dette område stammer særlig fra den såkalte Birmingham-skolen, som igjen bygde på biometrisk statistikk utviklet av blant andre den berømte statistikeren Ronald Fisher tidlig på 1900-tallet. Denne tradisjonen har kanskje mer enn noen annen bidratt til populasjonsgenetisk teori, statistikk og metode. I dag eksisterer det fortsatt en vital gren av atferdsgenetikken som baseres på data fra dyr, bl.a. bananfluer og mus. Selv om human og animalsk atferdsgenetikk har svært mye felles, er denne artikkelen begrenset til observasjoner av mennesker.

Trass i rask metodisk framgang, møtte atferdsgenetikken motbør mot midten av 70-tallet. Den politiske radikaliseringen i denne perioden, særlig på universitetene, førte til at atferdsgenetisk forskning i vide kretser ble ansett som politisk ukorrekt. I dag har pendelen svinget tilbake. Riktignok har tradisjonell atferdsgenetisk forskning kommet noe i skyggen av molekylærgenetisk forskning. Men vanlig tvilling- og familieforskning vil ikke kunne utkonkurreres av forskning på spesifikke gener. For det første er tradisjonelle studier fremdeles nødvendige for å rydde grunnen for molekylærgenetiske studier innen psykiatri: Det er bare meningsfullt å lete etter spesifikke gener for egenskaper eller forstyrrelser som viser forholdsvis høy arvelighet. Molekylærgenetisk forskning kan heller ikke besvare samme typer spørsmål som tvillling- og familiestudiene. Bare sistnevnte kan tallfeste relativ betydning av arv og miljø, både for bestemte forstyrrelser og for komorbiditeten mellom ulike forstyrrelser. Og ikke minst kan tradisjonelle studier benyttes til å beregne betydningen av ulike typer miljøforhold (se nedenfor) og dermed nyansere resultater basert på enkle genetiske forklaringsmodeller.

Fram til 60-tallet hadde atferdsgenetisk forskning stort sett nøyd seg med å estimere relativ betydning av arv og miljø. Utviklingen av varianskomponentberegninger ved hjelp av såkalte strukturelle likningmodeller (7) basert på stianalyse (8) førte til at man ble i stand til å besvare en rekke nye spørsmål. Både klassiske tvillingstudier og adoptivstudier gir informasjon som tillater å dele effekten av miljøfaktorer i to, nemlig i den delen som er felles for familien (eller for tvillingparet) og øvrig miljøeffekt, men denne muligheten hadde til da ikke vært utnyttet. Eksempler på miljøforhold som er felles for tvillinger og søsken er faktorer knyttet til bolig og boligområde, modell-læring fra foreldre og påvirkning fra søsken. Klassiske tvillingstudier kan bare gi estimater for samlet effekt av miljøforhold felles for tvillingsøsken, mens andre design, som adoptivstudier eller kombinasjoner av tvilling- og 
familiestudier, gir estimater for flere typer familiemiljø. Det er blitt vanlig å skille mellom miljømessig overføring fra foreldre til barn og miljøeffekter som bare deles av søsken (men ikke av foreldre og barn). Det er også vanlig å spesifisere disse effektene $\mathrm{i}$ henhold til kjønn: mor-datter, mor-sønn, far-datter, farsønn, søstre, brødre og søster-bror. På samme måte som for miljøeffekter, tillot økt kompleksitet av modellene at også effekter av gener ble beregnet separat for kjønn, og at genetiske effekter som gjelder for begge kjønn kunne separeres fra effekter som bare kommer til uttrykk hos et av kjønnene.

Enda viktigere er kanskje mulighetene knyttet til de såkalte multivariate analysene, en metodikk som ble utviklet mot slutten av 70-tallet (9). Ved å analysere flere fenotyper samtidig kan man beregne i hvilken grad statistisk samvariasjon (eller komorbiditet) skyldes at de samvarierende fenotypene påvirkes av samme gener og i hvilken grad sammenhengen er miljøbetinget. For eksempel har tvillingdata, bl.a. fra Norge $(10,11)$, vist at den sterke samvariasjonen som kan observeres mellom ulike typer intellektuelle evner, som verbale evner, korttidshukommelse, hoderegning og spatiale evner, i første rekke skyldes at de påvirkes av samme gener. IQ er altså en biologisk betinget entitet, ikke bare en sosial konstruksjon av ulike typer evner og ferdigheter. Psykiatriske multivariate studier kan danne grunnlag for et nytt diagnostisk klassifikasjonssystem basert på biologiske årsaksforhold. Hvis f.eks. fobier og generalisert angst viser seg å være uttrykk for samme gener, vil det være naturlig å gruppere disse diagnosene sammen eller nær hverandre i systemet. Hvis det derimot viser seg at de to lidelsene er genetisk uavhengige, vil de fortrinnsvis havne i ulike hovedgrupper.

I forlengelsen av multivariate metoder fulgte genetiske utviklingsstudier. Istedenfor å måle flere ulike fenotyper, måles den samme fenotypen gjentatte ganger over en viss aldersperiode og analyseres med longitudinelle modeller. Slike datasett gjør det mulig å tallfeste i hvilken grad endring over alder - f.eks. i depresjon - skyldes at effekten av bestemte gener "skrus på eller av", og eventuelt tar over for, eller erstattes av, andre gener ved bestemte alderstrinn. Parallelt beregnes i hvilken grad fenotypisk endring kan tilskrives endring i miljøet.

Som nevnt ble avansert atferdsgenetisk metodikk tatt i bruk nokså sent i psykiatrisk forskning. Dette særlig fordi metodene opprinnelig ble utviklet for observasjon av fenotyper som lar seg måle langs en kontinuerlig skala, slik som IQ, personlighetstrekk eller kroppshøyde. Det at psykiske lidelser vanligvis observeres som dikotome variable - 'syk' eller 'ikke syk' - forhindret lenge beregninger av styrken av arveligheten ("heritabilitetskoeffisienten"). Et unntak var data om selvrapporterte symptomer fra spørreskjemaer, som vanligvis observeres som kontinuerlig fordelte skårer, og som tidlig på 80-tallet ble analysert med avanserte metoder (12). Det finnes imidlertid betydelig skepsis innen psykiatrien mht. validiteten av slike spørreskjemadata. Dette trass i at hovedfunnene fra tvillingstudier av kliniske diagnostiske data og spørreskjema-data viser godt samsvar, i hvert fall for angst og lett og moderat depresjon (12-14). Hva angår kliniske data, ble styrken av genetisk effekt lenge målt som konkordanstall fra tvillinger, adoptivfamilier eller andre familier. Et problem med denne metoden er at konkordanstallene er avhengige av prevalensen for lidelsen som undersøkes. Er prevalensen svært høy, kan konkordanstallene bli relativt høye, og forskjellen mellom konkordans for eneggede og toeggede tvillinger relativt store, selv ved moderat genetisk innflytelse. Omvendt kan svært lav prevalens gi nokså lave konkordanstall. Konkordanstallene kan heller ikke uten videre brukes til å estimere betydningen av familiemiljøet.

En løsning for å komme rundt begrensningene ved dikotome data ble introdusert på 80-tallet (15). Det gjøres en antakelse om at det finnes en underliggende disposisjonen (liability) for å bli syk som er kontinuerlig fordelt. Hvis denne disposisjonen, som nødvendigvis er summen av genetiske og miljømessige risikofaktorer, overskrider en bestemt terskelverdi, oppstår sykdommen, ellers ikke. Figur 1 illustrerer dette. Disposisjon for en sykdom antas å variere langs hele $\mathrm{x}$-aksen, mens bare personer med verdier høyere enn terskelverdien $t$ blir syke. Skaleringen i figuren er tilfeldig. Spesielle mål for samsvar, tetrakoriske korrelasjoner (nærmere beskrevet senere), gir estimater av slektskapskorrelasjonene for tenkt underliggende disposisjon for en lidelse. Dette på tross av at det eneste som kan observeres er hvorvidt hver enkelt person befinner seg over eller under terskelverdien $t$. Slik genereres "pseudo-kontinuerlige" data fra dikotome data, noe som åpner for samme analyser av psykiatriske data som av trekk som kan måles langs et kontinuum.

Trass i en vridning mot molekylægenetisk forskning har det de siste årene kommet en mengde nye resultater fra tvillingundersøkelser av psykisk helse, ikke minst knyttet til dekomponering av genetiske og miljømessige kilder til komorbiditet. Likevel står de "nye" spørsmålene om komorbiditet, endring/stabilitet, ulike typer familiemiljø og kjønnsspesifikke effekter i hovedsak ubesvart.

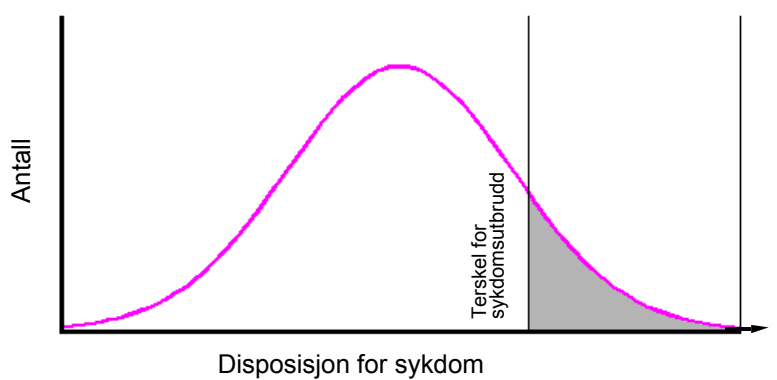

Figur 1. En modell for normalfordelt underliggende disposisjon for sykdom. 


\section{LITT MER OM METODER}

Det vi i dag regner som human atferdsgenetikk, omfatter tvilling-, adoptiv- og familiestudier og DNAstudier av spesifikke gener. Dessuten får betydningen av spesifikke gener en stadig større plass innen atferdsgenetiske forskningsmiljøer. DNA-forskningen har til nå gitt få eller ingen etterprøvde funn knyttet til psykiske lidelser. Dette henger kanskje sammen med at de ulike diagnostiske klassene ikke er "rene fenotyper" i genetisk forstand, en forklaring blant andre Einar Kringlen (16) har argumentert for. Kriterieorienterte klassifiseringssystemer som DSM og ICD er nyttige og relativt pålitelige redskaper for kliniske formål, men klassifiseringen er ikke basert på underliggende årsaksforhold. Hvis samme gener kan føre til ulike diagnoser og ulike gener kan føre til samme diagnose, vil det være vanskelig å produsere etterprøvbare resultater. Selv om DNA-forskning får en stadig større plass i atferdsgenetikken, vil den ikke bli nærmere omtalt her.

De vanligste typer undersøkelser i human atferdsgenetikk er klassiske tvillingstudier av eneggede og toeggede tvillinger vokst opp sammen, studier av eneggede tvillinger vokst opp fra hverandre, adoptivstudier, der adoptivbarn sammenliknes med biologiske slektninger og med medlemmer av adoptivfamilien, og studier av vanlige kjernefamilier. Det blir dessuten stadig vanligere å kombinere flere typer data, særlig tvillinger og deres foreldre, søsken og barn. I utgangspunktet gir kanskje adoptivstudiene og studier av tvillinger vokst opp fra hverandre sikrest og lettest fortolkbar informasjon. Korrelasjonene mellom biologiske slektninger som ikke deler miljøforhold gir et "rent" uttrykk for genenes betydning for en bestemt egenskap. På samme måte regnes likheten mellom adoptivbarnet og foreldre/søsken i adoptivfamilien å gi et "rent" uttrykk for miljøforhold knyttet til den enkelte familie. I praksis er det vanskelig å oppspore slektninger som har vært atskilt fra fødselen og som i alle relevante forhold er representative for normalpopulasjonen. Derfor har klassiske tvillingstudier hatt større betydning enn adoptivstudiene for atferdsgenetisk kunnskap. Hovedprinsippet for slike tvillingstudier er at større fenotypisk likhet mellom eneggede enn mellom toeggede gir uttrykk for betydningen av genene.

En annen form for adoptivdata kan tenkes å få større betydning i nær fremtid. Etter hvert er skilsmisser blitt svært vanlige. Skilte og gjengiftede foreldre betraktes ikke lenger som avvikende, men i mange henseende som representative for befolkningen. Det er ikke uvanlig at menn som har giftet seg med skilte mødre av små barn sosialt sett har fungerer som barnets far. Data fra slike adoptiv-/foster-/stefedre og barn og fra de samme barna og deres biologiske foreldre kan langt på vei erstatte data fra klassiske adoptivstudier. Stadig flere barn fra slike familier er i ferd med å bli voksne, og kan bidra med "voksenpsykiatriske" data, og gode registeropplysninger om fødsler, skils- misser og gjengifte gjør det mulig å identifisere dem.

Familiestudier er i utgangspunktet mindre informative enn tvilling- og adoptivstudier. Siden både foreldre og søsken gjennomsnittlig deler halvparten av genene, og alle familiemedlemmene også deler en del miljøforhold som er knyttet til familien, gir ikke slike studier grunnlag for å separere genetisk effekt fra miljøeffekt som er knyttet til familiene. Riktignok er slike studier velegnet til å estimere spesielle effekter, særlig genetiske effekter knyttet til X-kromosomet og kjønnsspesifikke miljøeffekter, men slike resultater kan først og fremst komplettere arv-miljø-beregninger fra andre typer undersøkelser. Trass i begrensningene ved informasjonen fra familiestudier, forekommer de relativt ofte i psykiatrisk forskning fordi det er lett å oppnå store datamaterialer. Særlig har det vært vanlig å undersøke pasientmaterialer og pasientenes nærmeste familie. Familiestudier fra normalutvalg er atskillig sjeldnere.

Modellene i moderne atferdsgenetikk baseres på stianalyse (17), som er et redskap til å estimere sammenhenger mellom ulike variable $i$ en på forhånd spesifisert årsaksmodell. Figur 2 viser en modell for hvilke kausale faktorer som påvirker en symptomskåre for generalisert angst og depresjon. Verdiene er hentet fra et norsk tvillingmateriale (18). Latente variable, som ikke kan observeres, symboliseres gjerne som sirkler, mens observerbare variable tegnes som rektangler. Den observerbare angst/depresjonsskåren bestemmes av en bestemt genotype, G, summen av miljøforhold som ikke er knyttet til familien, E (environment), og summen av miljøforhold som er knyttet til familien (eller mer presis, felles for tvillingsøsken), C (common environment). Disse er "latente", men vi tenker oss at hvis de kunne måles direkte, kunne vi hos hver enkelt person observere en verdi for hver av de latente variablene. Stikoeffisientene, $h, c$ og $e$, er standardiserte regresjonskoeffisienter, som tallfester betydningen av henholdsvis genetisk disposisjon, familiemiljø og annet miljø. Kvadratet av parameter-estimatene angir hvor stor del av variansen i befolkningen som bestemmes av hver av årsaksfaktorene. I følge Figur 2 er andelen av variansen som bestemmes av gener, heritabiliteten, $h^{2}, 0,41$. Andelen som bestemmes av familiemiljø, $c^{2}$, er 0,10 , og andelen som bestemmes av individuelt miljø, $e^{2}$, er 0,49 .

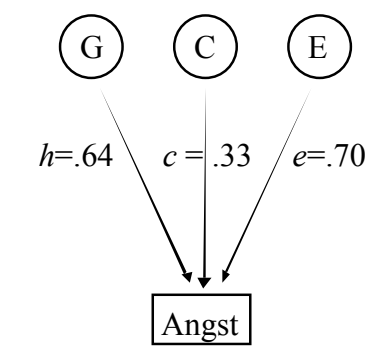

$$
\operatorname{Var}(\text { angst })=h^{2}+c^{2}+e^{2}=1
$$

Figur 2. Ulike kilder til fenotypisk variasjon. 
Hvordan er det så mulig å estimere disse stikoeffisientene når årsaksvariablene, G, C, og E, bare er teoretiske størrelser og ikke kan observeres? Figur 3 viser en sti-modell for den klassiske tvillingmetoden. Selv om vi ikke kan observere genetisk disposisjon, vet vi at eneggede tvillingsøsken har alle gener felles, korrelasjonen mellom genotypisk verdi for tvilling 1 $\left(G_{1}\right)$ og tvilling $2\left(G_{2}\right)$ er derfor 1,0 . Toeggede tvillinger har i gjennomsnitt halvparten av genene felles, som kan vises å gi en korrelasjon mellom genotypiske verdier på 0,5 . Familiemiljøet, eller miljøet som er felles for tvillingsøsken, C, er per definisjon det samme for begge tvillingsøsken, korrelasjonen er altså 1,0 for både eneggede og toeggede tvillinger. Korrelasjonen mellom $E_{1}$ og $E_{2}$ er per definisjon null.

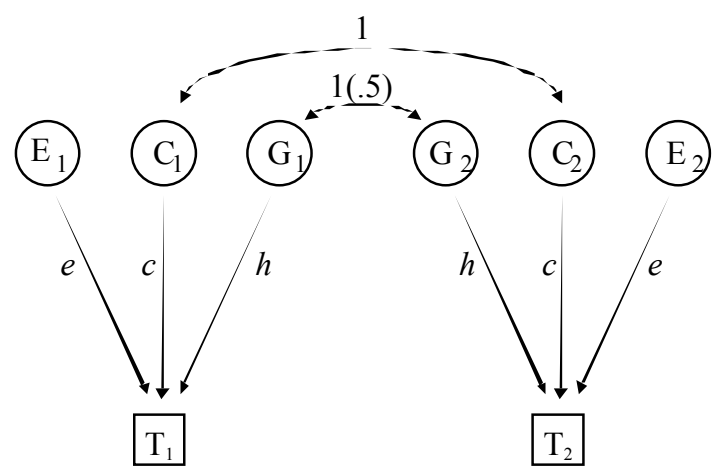

Figur 3. Ulike kilder til fenotypisk variasjon og samvariasjon mellom tvillingsøsken.

En hovedregel for stianalyse er at den observerte korrelasjonen mellom to variable er summen av produktet av alle korrelasjoner og stikoeffisienter som inngår i alle mulige stier mellom de to variablene. Mulige stier er alle tenkelige veier man beveger seg $i$ sti-diagrammet ved å bevege seg langs pilene. Man kan gå enten med eller mot pilretningene. Det er to mulige veier å bevege seg fra observert fenotype hos tvilling $1, T_{1}$, til observert fenotype hos tvilling $2, T_{2}$, nemlig $T_{1} \rightarrow \mathrm{C}_{1} \rightarrow \mathrm{C}_{2} \rightarrow T_{2}$ og $T_{1} \rightarrow \mathrm{G}_{1} \rightarrow \mathrm{G}_{2} \rightarrow T_{2}$. For eneggede tvillinger er produktet av første sti $c^{*} 1^{*} c$, altså $c^{2}$, og av andre sti, $h^{*} 1^{*} h=h^{2}$. Korrelasjonen mellom $T_{1}$ og $T_{2}$ for eneggede kan dermed uttrykkes som $r_{\mathrm{T} 1-\mathrm{T} 2}=h^{2}+c^{2}$. Uttrykket for fenotypisk korrelasjon hos toeggede er nesten det samme, men her er korrelasjonen mellom $\mathrm{G}_{1}$ og $\mathrm{G}_{2}$ ikke 1,0, men 0,5 , altså blir $r_{\mathrm{T} 1-\mathrm{T} 2}=0,5 h^{2}+c^{2}$ for toeggede. Ved hjelp av disse to likningene, hvor $h^{2}$ og $c^{2}$ er ukjente, kan man beregne verdien av $h \operatorname{og} c$. Enkel algebra viser at hvis $r_{\mathrm{T} 1-\mathrm{T} 2}$ observeres til 0,52 blant eneggede og 0,32 blant toeggede, dvs.

$$
\begin{aligned}
h^{2}+c^{2} & =0,52 \\
\text { og } \quad 0,5 h^{2}+c^{2} & =0,32
\end{aligned}
$$

vil heritabiliteten få verdien $h^{2}=0,44$ og effekten av familiemiljøet vil være $c^{2}=0,11$.
Modellen for den klassiske tvillingundersøkelsen er enkel, og i sin enkleste form tillater den, i motsetning til mer komplekse modeller, at likningene løses ved håndregning. Andre modeller krever bruk av strukturelle likning-dataprogrammer som LISREL (19). Selv ved klassiske tvillingstudier gir bruk av slike teknikker fordeler, bl.a. ved beregning av feilmarginer for estimatene. En begripelig framstilling av slike redskap krever mer plass enn hva som står til rådighet her.

Figur 4 er et stidiagram for en fenotype målt hos far, $F$, mor, $M$ og to barn, $B_{1}$ og $B_{2}$. Fenotypisk verdi for hver av familiemedlemmene, $F, M, B_{1}$ og $B_{2}$, bestemmes av genetisk disposisjon, $\mathrm{G}$, og av summen av alle miljøfaktorer, E. Sti- (regresjons-)koeffisienten for effekten av foreldrenes genotype på barnas genotype er 0,5. Koeffisientene $h$ og $e$ angir styrken på henholdsvis genetisk effekt og samlet miljøeffekt. Modellen avviker fra den klassiske tvillingmodellen ved at det ikke defineres noen egen latent variabel for familiemiljø som virker direkte på fenotypen. Samlet miljø $\left(\mathrm{E}_{\mathrm{B} 1}\right.$ og $\left.\mathrm{E}_{\mathrm{B} 2}\right)$ består av alle miljøforhold som ikke er knyttet til familien, men også av faktorer som er knyttet til familien i form av påvirkninger fra foreldrenes fenotype, F og M, og miljøfaktorer som bare er felles for søsken, S. Styrken av overføring fra foreldrenes fenotype, f.eks. ved rollelæring, angis ved $c$, og styrken av miljøpåvirkning som er felles for søsken angis ved $s$. Parameterne $e$ og $c$ er derfor ikke helt identiske med dem fra tvillingmodellen.

Modellen vist i Figur 4 er ikke identifisert, dvs. at de observerte korrelasjonene mellom familiemedlemmenes fenotyper ikke gir tilstrekkelig informasjon til å beregne alle parameterverdiene, og som nevnt ikke gir adgang til separasjon av arv og familiemiljø. Undersøkelser av adoptivstudier, derimot, hvor et av barna (eksempelvis $B_{l}$ ) er adoptert, tillater disse beregningene. Her vil korrelasjonen mellom adoptivforeldrene, $F$ og $M$, og adoptivbarnet, $B_{1}$, bare avhenge av miljømessig overføring, $f$ og $m$, fordi genetisk overføring fra $\mathrm{G}_{\mathrm{F}}$ og $\mathrm{G}_{\mathrm{M}}$ til $\mathrm{G}_{\mathrm{B} 1}$ faller bort. Søskeneffekten, $s$, er den samme for barn og adoptivbarn. Ved undersøkelser av adoptivbarnet og dets biologiske familie er $f, m$ og $s 0$ for adoptivbarnet.

Så langt har metodebeskrivelsen dreiet seg om univariate analyser, hvor bare ett observert trekk hos hver av slektningene inngår. Figur 5 illustrerer et eksempel på en analyse av to observerte trekk. En skåre for symptomer på generalisert angst og depresjon (en kortversjon av SCL-25) og selvrapportert alkoholforbruk ble innhentet fra ca. 5000 norske tvillinger fra 18 til 25 år (20). Resultatene vist i figuren gjelder for menn. Stikoeffisientene, som må kvadreres for å uttrykke andel forklart varians, viser at spesifikke gener for angst/ depresjon, $\mathrm{G}_{\mathrm{AD}}$, kan tilskrives $0,55^{2}$, eller $30 \%$ av totalvariansen, gener felles for angst/depresjon og alkoholforbruk, $\mathrm{G}_{\mathrm{F}}$, kan tilskrives $0,42^{2}$, eller $18 \%$. Miljøforhold som ikke er knyttet til familien og som er spesifikke for angst/depresjon, $\mathrm{E}_{\mathrm{AD}}$, forklarer $0,68^{2}$, eller $47 \%$ av variansen, og familiemiljø felles for 
angst/depresjon og alkohol, $\mathrm{C}_{\mathrm{F}}$, forklarer $0,22^{2}=5 \%$ av variansen. De tilsvarende effektene for alkoholforbruk er i samme størrelsesorden. Det er ingen effekt av ikke-familiært miljø felles for de to fenotypene, $E_{F}, o g$ ingen effekt av familiemiljø spesifikke for hver av fenotypene, $\mathrm{C}_{\mathrm{AD}}$ og $\mathrm{C}_{\mathrm{AL}}$. I tillegg til resultatene som kan fås fra separate analyser av hver av fenotypene, viser den bivariate analysen at korrelasjonen mellom symptomer på angst/depresjon og alkoholforbruk i hovedsak ser ut til å avspeile effekt av gener som er felles for begge fenotypene. Resultatene for kvinner var noe annerledes, her bidro både gener og miljømessige faktorer til korrelasjonen mellom angst/depresjon og alkoholforbruk.

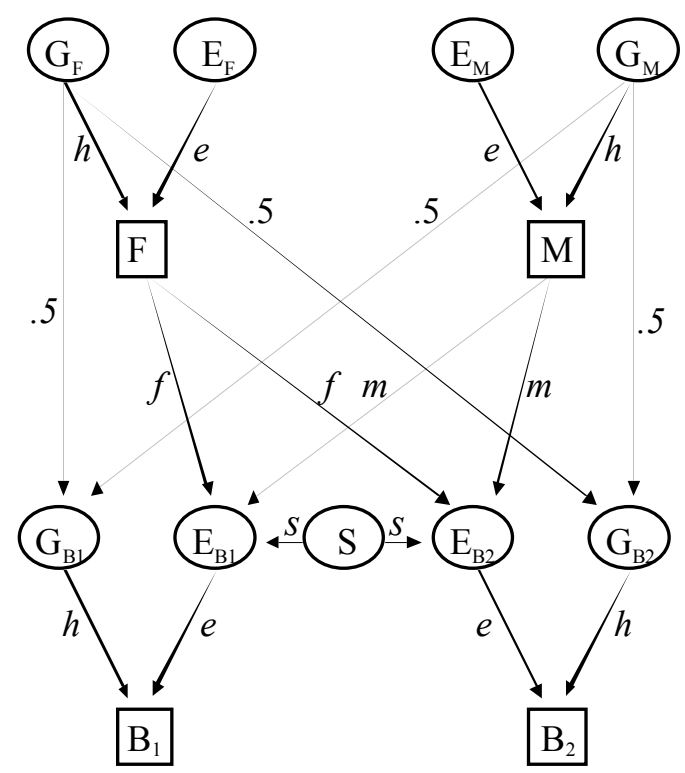

Figur 4. En modell for genetisk og miljømessig overfø-

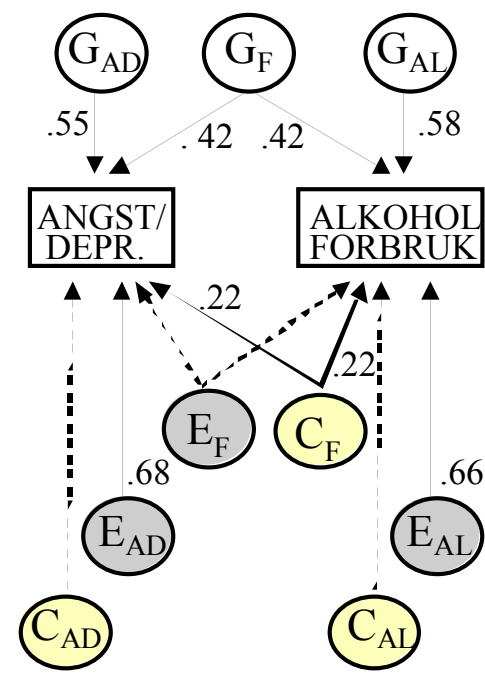

ring fra foreldre til barn.

Figur 5. Relativ betydning av gener og miljøforhold for angst/depresjon og alkoholforbruk og for samvariasjonen mellom disse målene.
Metodene som er beskrevet forutsetter i utgangspunktet at trekkene som undersøkes kan måles langs en kontinuerlig skala, mens de fleste psykiatriske data er binære av typen 'kasus' eller 'ikke kasus'. Som nevnt er det likevel mulig å komme rundt denne begrensningen. Det gjøres en antakelse om en underliggende disposisjon eller risiko for å bli syk som er en kontinuerlig, normalfordelt variabel. Denne underliggende variabelen er summen av genetiske og miljømessige faktorer som disponerer for sykdom. Sykdommen manifesterer seg bare i de tilfelle hvor den underliggende variabelen overstiger en bestemt terskelverdi (området av X-aksen over den skraverte delen av fordelingen $\mathrm{i}$ Figur 1 og 6). Vi tenker oss at det vi egentlig ønsker å analysere, er den underliggende variabelen. Kunne vi måle den, f.eks. i et utvalg med mødre og barn, ville vi også kunne observere slektskapslikhet i form av en vanlig Pearson-korrelasjon (det vanligste målet for samvariasjon mellom kontinuerlig fordelte variable). Figur 6 illustrerer dikotome data for slektninger (f.eks. mødre og barn) hvor det antas en underliggende normalfordelt disposisjon for å bli syk. Normalfordelingskurver for de antatte underliggende variablene er tegnet langs hver av aksene. De faktisk observerte dataene er redusert til 0 eller 1 for mødrene og barna, slik at slektskapslikheten observeres $\mathrm{i}$ form av en firefeltstabell med utfallene 0-0, 1-0, 0-1 eller 1-1 for henholdsvis mor og barn (henholdsvis celle $\mathrm{d}, \mathrm{c}, \mathrm{b}$ og a i Figur 6). Det er likevel mulig å regne seg tilbake til Pearson-korrelasjonen for de underliggende kontinuerlige variablene bare ved hjelp av prosentfordelingene $\mathrm{i}$ firefeltstabellen fordi arealene over og under terskelverdiene er bestemt av fordelingen i firefeltstabellen. Likeledes er det mulig å beregne verdien av en Pearson-korrelasjon mellom de underliggende variablene på grunnlag av den samvariasjonen mellom mor og barn som framgår av firefeltstabellen. En "simulert" Pearson-korrelasjon basert på dikotomiserte variable kalles en tetrakorisk korrelasjon. Gitt en bestemt underliggende bivariat normalfordeling vil korrelasjonen være uavhengig av hvor terskelverdiene for sykdomsdefinisjon befinner seg. Derfor kan tetrakoriske korrelasjoner - og arvelighetsberegninger som bygger på slike korrelasjoner - i motsetning til konkordanstall fortolkes uavhengig av prevalensen for den aktuelle lidelsen. Dette har blant annet den fordel at krysskulturelle forskjeller i diagnostisk praksis ikke trenger å påvirke resultatene for genetiske analyser. For eksempel vil det ikke spille noen rolle for resultatene hvilket symptomnivå som skal til i en bestemt populasjon for å få diagnosen "generalisert angst" så lenge typen symptomer som legges til grunn ikke varierer.

Bruk av tetrakoriske korrelasjoner eller lignende teknikker er i ferd med å bli standard prosedyre innen psykiatrisk atferdsgenetikk. Men selv om lave prevalenser ikke systematisk påvirker de statistiske forventningene av arvelighetsestimatene, er usikkerhetsmarginene like fullt høye når prevalensen er lav, slik at det er heftet høy usikkerhet til en stor del av resulta- 
tene. Det er imidlertid enkelt å reanalysere eksisterende resultater rapportert som konkordanstall ved hjelp av tetrakoriske korrelasjonsberegninger, og resultatene vil være sammenliknbare selv om konkordanstallene varierer på grunn av ulike prevalenstall.



Figur 6. En modell for bivariat underliggende disposisjon for sykdom blant slektninger med korrelerte fenotyper.

\section{NOEN RESULTATER FRA ANALYSER AV ANGST OG DEPRESJON}

\section{Heritabilitetsanalyser}

Selv om angst og depresjon er fenomenologisk og klinisk forskjellige, er svært mange symptomer felles, og sjekklister som SCL-25, som gir skårer for henholdsvis generalisert angst og depresjon (21) viser gjerne korrelasjoner på 0,70-0,75 mellom angst- og depresjonsskårene. Symptomer klassifisert som angst samvarierer nesten like høyt med depresjonssymptomer som henholdsvis angst- og depresjonssymptomer samvarierer innbyrdes. Klinisk erfaring viser at generalisert angst predisponerer for senere depresjonslidelse og vice versa. Som jeg skal komme tilbake til, viser også tvillingstudier at de to typene symptomer kan betraktes som elementer av samme diagnostiske hovedgruppe. Noen av undersøkelsene som vil bli beskrevet i det følgende skiller ikke mellom de to typene symptomer. En oversikt over resultater fra tvilling- og familiestudier av symptomer på generalisert angst og/eller depresjon er vist $\mathrm{i}$ Tabell 1. Den norske tvillingundersøkelsen viser noe høyere arvelighet enn de andre, men generelt er det brukbar overensstemmelse mellom resultatene. Av hensyn til sammenliknbarheten er bare spørreskjemaundersøkelser fra normalutvalg inkludert.

\section{Multivariate analyser}

Jardine og medarbeidere (12) var de første som med moderne multivariat tvillingmetodologi undersøkte genetiske sammenhenger mellom symptomer på generalisert angst og depresjon. 3810 tvillingpar fra en australsk normalpopulasjon besvarte sjekklister for angst og depresjon og dessuten Eysenck's neurotisisme-skala (22). De tre skårene korrelerte alle rundt 0,60 med hverandre. Genetiske og miljømessige kilder til varians er vist i Figur 7. Totalt er effektene av miljøforhold som ikke er knyttet til familien noe sterkere enn genetiske effekter, mens familiemiljøet ikke ser ut til å spille noen rolle i det hele tatt. Størsteparten av genetisk effekt er fra felles gener, $G_{F}$. Omtrent halvparten av miljøeffektene ser ut til å være felles, de andre spesifikke for hver enkel skåre. Resultatene gjengitt i figuren gjelder for kvinnelige tvillinger, men resultatene var nesten identiske for menn.

En undersøkelse av selvrapporterte symptomer på angst og depresjon i kjernefamilier (23) er i full overensstemmelse med tvillingundersøkelsene. 8096 personer besvarte et spørreskjema fra Statistisk sentralbyrås Helseundersøkelse 1985. Utvalgsenheten var husstand,

Tabell 1. Genetiske analyser av angst og depresjon fra noen store tvillingundersøkelser. Normalutvalg med symptomer i spekteret normal til alvorlig.

\begin{tabular}{|c|c|c|c|c|c|c|c|}
\hline Befolkning, forfattere & Antall indiv. & Type slektninger & Symptomtype & Gruppe & $h^{2}$ & $\mathrm{c}^{2}$ & $\mathrm{e}^{2}$ \\
\hline \multirow[t]{4}{*}{ Australia, Jardine et al. (1984) } & 7620 & Tvillinger & Angst & Menn & 0,34 & 0,00 & 0,66 \\
\hline & & & & Kvinner & 0,38 & 0,00 & 0,62 \\
\hline & & & Depresjon & Menn & 0,34 & 0,00 & 0,66 \\
\hline & & & & Kvinner & 0,32 & 0,00 & 0,68 \\
\hline USA, Silberg et al. (1990) & 1542 & Tvillinger & Depresjon & Kvinner & 0,29 & 0,13 & 0,58 \\
\hline USA, Kendler et al. (1994) & 30445 & $\begin{array}{l}\text { Tvillinger med for- } \\
\text { eldre, søsken og barn }\end{array}$ & Depresjon & & & & \\
\hline Norge, Tambs et al. (1995) & 5140 & Tvillinger & $\begin{array}{l}\text { Angst og } \\
\text { depresjon }\end{array}$ & $\begin{array}{l}\text { Menn og kvinner, } \\
\text { ingen kjønnsforskjell }\end{array}$ & 0,41 & 0,11 & 0,48 \\
\hline \multirow[t]{2}{*}{ Norge, Tambs (1990) } & 8096 & $\begin{array}{l}\text { Foreldre,barn og } \\
\text { søsken }\end{array}$ & Angst & $\begin{array}{l}\text { Menn og kvinner, } \\
\text { ingen kjønnsforskjell }\end{array}$ & 0,45 & - & 0,55 \\
\hline & & & Depresjon & & 0,41 & - & 0,59 \\
\hline
\end{tabular}


de fleste av deltakerne kunne derfor grupperes i familier. I motsetning til tvillingdata gir ikke familiedata anledning til å teste hvorvidt noe av familielikheten faktisk skyldes miljøforhold. Ut fra sammenlikning med resultater fra tvillingstudier var det rimelig å anta at all familielikhet unntagen noe av søskenlikheten skyldtes gener. Gitt denne antakelsen impliserte resultatene at størsteparten av genetisk effekt er felles for angst og depresjon, men at det finnes en moderat spesifikk genetisk effekt for angst.

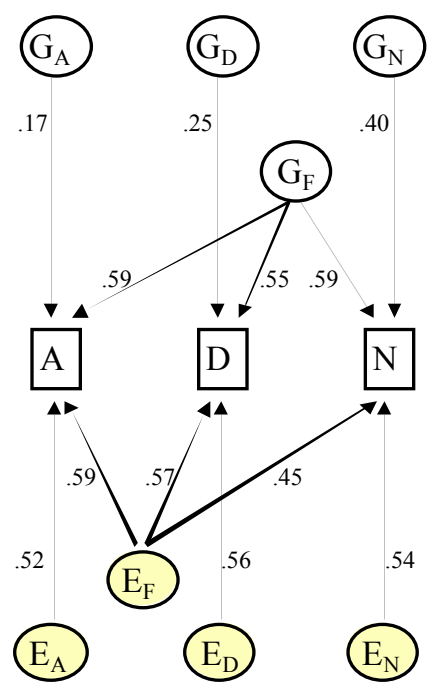

Figur 7. Genetisk og miljømessig betydning for angst, depresjon og nevrotisisme og for samvariasjonen mellom disse målene.

Få tvillingundersøkelser har vakt større oppsikt enn Kendler og medarbeideres arbeide om alvorlig depresjon og generalisert angstlidelse $i$ et populasjonsbasert utvalg (14). 1033 kvinnelige par fra Virginia ble intervjuet med SCID (24). Resultatene for alvorlig depresjon (MD) og generalisert angstlidelse av minst én måneds varighet (GAD) er vist i Figur 8 . Samlet genetisk effekt er omtrent den samme, 0,3-0,4 for begge variablene. (Merk at estimatene for andel forklart varians fås ved å kvadrere de estimerte stikoeffisientene vist $\mathrm{i}$ figurene.) Bare henholdsvis tre prosent $\left(0,17^{2}\right)$ og fem prosent $\left(0,25^{2}\right)$ av variansen for spørreskjemadataene er forklart av spesifikke gener, og for intervjudata er disse effektene fraværende. Det er ingen effekt av familiemiljøet. Omtrent halvparten av øvrig miljøeffekt er felles for de to variablene, mens den andre halvparten er spesifikk for angst eller depresjon.

En ikke populasjonsbasert tvillingundersøkelse nyanserer antakelig bildet noe. Torgersen presenterte resultater fra en undersøkelse av probander med 1) alvorlig depresjon uten angst, 2) alvorlig depresjon med angst og 3) angstforstyrrelser uten depresjon (25). Eneggede og toeggede tvillingsøsken av probandene ble klassifisert etter samme diagnosegrupper. Resultatene tyder på en sterk genetisk sammenheng mellom de to første gruppene, men ikke mellom de to første og den tredje gruppen. Denne tendensen ble enda klarere da bare angstlidelser med panikkangst ble medregnet $\mathrm{i}$ gruppe tre, noe som tyder på at spesifikke gener i første rekke koder for panikkangst, mens generalisert angst i hovedsak påvirkes av samme gener som depresjon.

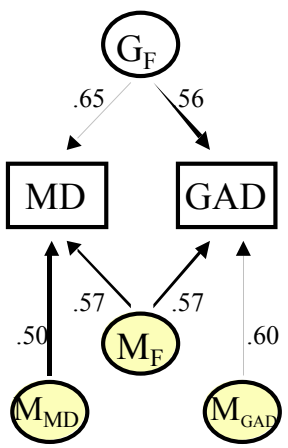

Figur 8. Genetisk og miljømessig betydning for alvorlig depresjon og generalisert angstforstyrrelse og for samvariasjonen mellom disse målene.

\section{En modell for effekter av aldersspesifikke gener}

Angst- og depresjonslidelser viser ingen sterk systematisk sammenheng med alder, men det enkelte individ kan oppleve store forskjeller mellom ulike faser av livet. Dette kan selvsagt ha sammenheng med endrede miljøforhold, deriblant terapeutisk behandling, men det kan også tenkes at ulike gener har ulik betydning ved ulike aldre, og at kanskje noen har gener som fører til depresjon tidlig i livet, mens andre har gener som gir depresjon senere. Longitudinelle data fra tvillinger eller andre slektninger er velegnede for å estimere aldersspesifikke genetiske effekter og aldersspesifikke eller temporære miljøeffekter. Så vidt jeg vet finnes ikke store tvilling- eller familiematerialer med gjentatte observasjoner av angst/depresjon gjennom store deler av livet, og å bygge opp et slikt materiale tar selvsagt lang tid. Store tverrsnittsmaterialer med data fra slektninger kan imidlertid også gi informasjon om slike aldersspesifikke eller temporære trender. Logikken er at aldersspesifikke gener vil gi korrelasjoner mellom slektninger som avtar med aldersforskjell. Det kan vises at under en bestemt statistisk modell (26), kan korrelasjonene mellom slektninger uttrykkes som $\mathrm{r}=\tau \mathrm{e}^{-\mathrm{A} \delta \mathrm{e}}+\varepsilon \mathrm{e}^{-\mathrm{A} \delta \mathrm{h}}$, hvor A angir aldersforskjellen $\mathrm{i}$ år, $\tau$ og $\varepsilon$ er slektskapskorrelasjonene for henholdsvis genotypiske og miljømessige verdier når alle aldersspesifikke effekter er delt (når $\mathrm{A}=0$ ). $\delta_{\mathrm{e}}$ and $\delta_{\mathrm{h}}$ er parametre som uttrykker reduksjonen i korrelasjon med aldersforskjeller.

Data fra ulike typer slektninger fra Helseundersøkelsen i Nord-Trøndelag 1984-86 ble analysert med hensyn på aldersspesifikke/temporære effekter (27). Selvrapport-målet for symptomer på angst og depresjon er ikke systematisk utprøvd, men korrelerer 0,83 med totalskåren for SCL-25. Korrelasjoner mellom 
slektninger for angst/depresjon er vist i Tabell 2. Korrelasjonene tilsier en lavere arvelighet enn resultatene fra tvillingstudiene vist $\mathrm{i}$ Tabell 1 . Tabell 3 og 4 viser korrelasjoner for henholdsvis mor og barn og søskenpar med ulik aldersforskjell. Av plasshensyn er det ikke vist tilsvarende tabeller for andre typer slektninger og ikke kjønnsspesifikke statistikker for barn og søsken. Søskenkorrelasjonene synker signifikant med aldersforskjell, mens en tilsvarende trend for mødre og barn ikke var signifikant. En modell der reduksjonen i korrelasjonsverdier med aldersforskjell skyldes tidsspesifikke felles miljøforhold passer nesten like godt til dataene som en modell der denne reduksjonen spesifiseres som uttrykk for aldersspesifikke gener. Disse resultatene er derfor ikke fullstendig konklusive, men siden andre undersøkelser viser beskjedne effekter av familiemiljøet er det neppe sannsynlig at den sterke negative sammenhengen mellom aldersforskjell og fenotypisk likhet blant søsken skyldes miljøforhold. Tabell 5 viser parameterestimatene for de to beste modellene som spesifiserer henholdsvis genetisk alderseffekt og tidsspesifikk effekt delt mellom brødre og mellom søstre (men ikke mellom bror og søster). Parameter $h$ uttrykker arvelighet, $c_{F}$ er miljømessig overføring fra far, $c_{M}$ er miljømessig overføring fra mor, $s_{B}$ er miljøeffekter som er felles for brødre, $s_{S}$ er miljøeffekter som er felles for søstre, $s_{B S}$ er miljøeffekter som er felles for bror og søster og $e$ er total effekt av miljøforhold. Andel av totalvariansen i befolkningen som skyldes gener uttrykkes som $h^{2}$, andel som skyldes miljøforhold er $e^{2}$, andel som skyldes miljømessig overføring fra far og mor er $\left(c_{F}^{2}+c_{M}{ }^{2}\right) e^{2}$ (noe forenklet fordi en liten effekt av partnerlikhet her er utelatt). Andelen som skyldes miljøforhold felles for henholdsvis brødre, søstre, og bror-søster er $s_{B} e^{2}, s_{S} e^{2}$ og $s_{B S} e^{2}$. Parameterestimatene fra den første modellen i Tabell 5 viser at heritabiliteten, $h^{2}$, er 0,19 , mens samlet miljøeffekt, $e^{2}$, utgjør 0,81 av totalvariansen. Miljøvarians som skyldes overføring fra foreldre er 0,04 , mesteparten fra mor, og miljøeffekt av forhold som er felles for brødre, søsken og bror-søster er henholdsvis 0,02, 0,08 og 0. Parameterestimatet for aldersspesifisitet av gener, $\delta_{\mathrm{h}}=0,07$, impliserer at gjennomsnittlig er halvparten av effekten av de gener som påvirker angst og depresjon ved en bestemt alder byttet ut med effekten av andre gener 20 år senere.

\section{OPPSUMMERING}

Dette kapittelet har ikke gitt noe helhetlig bilde av metoder i psykiatrisk atferdsgenetikk, og resultatene som ble presentert er ikke stort mer enn smakebiter. De viser likevel en del forholdsvis entydige trender. For det første synes effekten av miljøfaktorer knyttet til familien å være beskjeden for angstforstyrrelser og depresjon. Den samme trenden er for øvrig fullstendig entydig for personlighetstrekk (28). Det siste ordet er likevel neppe sagt i denne sammenheng. Manglende evidens for miljøbestemt familielikhet for personlighet og psykiske lidelser kan til dels skyldes at hvert enkelt familiemedlem behandles ulikt, eller at noen familiemedlemmer kanskje inntar komplementære roller. Ikke desto mindre bør mangelen på evidens for effekter av familiemiljø vekke ettertanke, etter som mye av psykologisk og psykiatrisk teori tilsier at kilder til personlighetsutvikling og psykopatologi særlig er å finne i familien.

Dette betyr ikke at miljøforhold har liten betydning for utvikling av psykopatologi, i hvert fall ikke for symptomer på generalisert angst og depresjon. Tvert imot ser miljøforhold som ikke kan knyttes til familien ut til å bety mer enn gener. Estimatet for denne typen miljøeffekter rommer effekter av målefeil og dag-tildag-fluktuasjoner, men selv om det tas høyde for denne feilkilden, er miljøforhold antakelig vel så viktige som gener. Resultater som ikke er vist her tyder på at genetisk effekt er noe viktigere for relativt alvorlige lidelser, som alvorlig generalisert angstforstyrrelse og alvorlig depresjon, enn ved mildere former, som oftere måles med spørreskjema.

Tabell 2. Kjønnsspesifikke korrelasjoner mellom slektninger for symptomer på angst og depresjon.

\begin{tabular}{lcc}
\hline Type slektskap & $\mathrm{r}$ & Antall par \\
\hline Ektefeller & 0,27 & 18768 \\
Far-sønn & 0,14 & 7712 \\
Far-datter & 0,12 & 6281 \\
Mor-sønn & 0,17 & 9384 \\
Mor-datter & 0,17 & 7511 \\
Brødre & 0,12 & 4103 \\
Søstre & 0,18 & 2712 \\
Bror-søster & 0,11 & 6319 \\
Eneggede tvillinger, menn & 0,23 & 26 \\
Eneggede tvillinger, kvinner & 0,35 & 31 \\
Toeggede tvillinger, menn & 0,10 & 35 \\
Toeggede tvillinger, kvinner & $-0,06$ & 25 \\
Halvbrødre & 0,18 & 45 \\
Halvsøstre & 0,50 & 20 \\
Halvbror-halvsøster & 0,20 & 60 \\
Halvsøsken sammen & 0,30 & 85 \\
Halvsøsken atskilt & 0,16 & 40 \\
\hline
\end{tabular}

Tabell 3. Korrelasjoner mellom mor og barn med ulik aldersforskjell for symptomer på angst og depresjon.

\begin{tabular}{ccc}
\hline Aldersforskjell år & $\mathrm{r}$ & Antall par \\
\hline $14-19$ & 0,20 & 692 \\
$20-21$ & 0,18 & 1336 \\
$22-23$ & 0,14 & 1849 \\
$24-25$ & 0,18 & 1993 \\
$26-27$ & 0,15 & 2113 \\
$28-29$ & 0,16 & 1944 \\
$30-31$ & 0,17 & 1707 \\
$32-33$ & 0,20 & 1502 \\
$34-35$ & 0,18 & 1192 \\
$36-37$ & 0,21 & 974 \\
$38-39$ & 0,14 & 693 \\
$40-41$ & 0,14 & 502 \\
Over 41 & 0,06 & 383
\end{tabular}


Tabell 4. Korrelasjoner mellom søsken med ulik aldersforskjell for symptomer på angst og depresjon.

\begin{tabular}{ccc}
\hline Aldersforskjell år & $\mathrm{r}$ & Antall par \\
\hline 1 & 0,21 & 952 \\
2 & 0,16 & 1941 \\
3 & 0,13 & 1702 \\
4 & 0,13 & 1609 \\
5 & 0,12 & 1378 \\
6 & 0,12 & 1102 \\
7 & 0,13 & 949 \\
8 & 0,10 & 804 \\
9 & 0,11 & 607 \\
$10-11$ & 0,13 & 899 \\
$12-13$ & 0,11 & 555 \\
14 eller mer & 0,06 & 629 \\
\hline
\end{tabular}

I hovedsak er det de samme genene som disponerer både for generalisert angst og depresjon. Likevel kan enkelte former for angst og depresjon, som panikkangst, være påvirket av spesifikke gener. Det er dels de samme, dels forskjellige typer miljøforhold som har betydning for angst og for depresjon. Det betyr at siden genene stort sett er de samme for begge typer lidelser, er det spesifikke miljøforhold som avgjør om et disponert individ utvikler generalisert angst eller depresjon. I genetisk forstand er generalisert angst og depresjon to former av samme lidelse.

Familiedata fra Nord-Trøndelag indikerer at det finnes aldersspesifikke gener for angst og depresjon som skrus av eller på ved ulike aldre. Uheldigvis kan vi ikke utelukke en alternativ fortolkning, nemlig at miljøforhold som deles av søsken fører til større likhet mellom søsken på omtrent samme alder enn blant søsken som er mer ulike i alder. Siden den beskrevne unders $ø$ kelsen er den eneste i sitt slag for angst og depresjon - og så vidt jeg vet for psykisk helse i det hele tatt - har jeg likevel benyttet anledningen til å gi en kort beskrivelse. Nye store tverrsnittsundersøkelser, og etter hvert longitudinelle undersøkelser, vil sikkert gi klarere svar på hvorvidt det er gener og eller miljøfaktorer som i første rekke fører til endring gjennom livsløpet.

De resultatene som er beskrevet i dette kapittelet representerer selvsagt bare en lite flik av hva som allerede finnes av evidens fra psykiatriske tvilling-, adoptiv- og familiestudier. Likevel er det aller meste ennå ugjort av de typer studier som er skissert her. Særlig er det et stort behov for populasjonsbaserte studier av ensartede diagnostiske grupper basert på intervjuer eller andre valide diagnostiske prosedyrer. Ved siden av klassiske tvilling- og adoptivmetoder, vil metoder som omfatter flere typer relasjoner samtidig, kunne gi ny kunnskap. Data fra barn og deres skilte og gjengiftede biologiske foreldre og steforeldre kan gi mye av den samme informasjon som tradisjonelle adoptivstudier, og etter hvert som flere og flere barn av skilte foreldre blir voksne, vil slike data få stor betydning. Nordiske land har forholdsvis lav befolkningsmobilitet og gode befolkningsregistre, blant annet landsomfattende familie- og tvillingregistre, noe som har gitt anledning til viktige bidrag til psykiatrisk atferdsgenetikk. Blant andre Einar Kringlen og Svenn Torgersen ved Universitetet i Oslo var tidlig ute med viktige resultater. I framtida blir det forhåpentligvis også mulig å få tilgang til psykiatriske sykdomsregistre. Lett tilgang til gode data tilsier at vi fortsatt bør satse på slik forskning.

Tabell 5. Parameter-estimater og modelltilpasning for angst/depresjon i familier.

\begin{tabular}{|c|c|c|c|c|c|c|c|c|c|c|c|c|c|}
\hline Modell & $\mathrm{h}$ & $c_{F}$ & $c_{M}$ & $\mathrm{~s}_{\mathrm{B}}$ & $\mathrm{S}_{\mathrm{S}}$ & $\mathrm{s}_{\mathrm{BS}}$ & $\mathrm{e}$ & $\delta_{\mathrm{h}}$ & $\delta_{\mathrm{s}}$ & $\chi^{2}$ & df & $\mathrm{p}$ & AIC \\
\hline 1 & 0,43 & 0,09 & 0,16 & 0,17 & 0,32 & - & 0,90 & 0,067 & - & 109,74 & 101 & 0,260 & $-92,26$ \\
\hline 2 & 0,45 & - & 0,09 & 0,27 & 0,43 & - & 0,89 & - & 0,163 & 111,70 & 102 & 0,240 & $-92,30$ \\
\hline
\end{tabular}

Merk: Modellen for tidsspesifikke miljøfaktorer (modell 2) spesifiserer bare alders-/tidsavgrensede effekter av miljøforhold som deles av søsken, ikke av generelle miljøforhold $(e)$, derfor betegnelsen $\delta_{\mathrm{s}}$ heller enn $\delta_{\mathrm{e}}$.

\section{REFERANSER}

1. Galton F. The history of twins as a criterion of the relative powers of nature and nurture. Journal of the Anthropology Institute 1875; 5: 391-406.

2. Merriman C. The intellectual resemblance of twins. Psychological Monographs 1924; 33: 1-58.

3. Freeman FN, Holzinger KJ, Mitchell BC. The influence of environment on the intelligence, school achievement, and conduct of foster children. Yearbook of the National Society for the Study of Education 1928; 27 (1): 103-217.

4. Burks BS. The relative influence of nature and nurture upon mental development; a comparative study of foster parent - foster child resemblance and true parent - true child resemblance. Yearbook of the National Society for the Study of Education 1928; 27 (1): 219-316. 
5. Kallman FJ. The Genetics of Schizophrenia. J.J. Augustin, Locus Valley, NY, 1938.

6. Heston LL. Psychiatric disorders in foster home reared children of schizophrenic mothers. Br J Psychiatry 1966; 112: 819-825.

7. Bollen KA. Structural Equations with Latent Variables. Wiley, New York, 1989.

8. Kenny DA. Correlation and Causality. Wiley, New York, 1979.

9. Martin NG, Eaves LJ. The genetical analysis of covariance structure. Heredity 1977; 53: 89-95.

10. Tambs K, Sundet JM, Magnus P. Genetic and environmental contribution to the covariation between the WAIS subtests. A study of twins. Behav Genet 1986; 16: 475-491.

11. Tambs K, Sundet JM, Magnus P. Genetic and environmental effects on the covariance structure of the Norwegian Army ability tests. A study of twins. Pers Indiv Differ 1988; 9: 791-799.

12. Jardine R, Martin NG, Henderson AS. Genetic covariation between neuroticism and symptoms of anxiety and depression. Genet Epidemiol 1984; 1: 89-107.

13. Kendler KS, Heath AC, Martin NG, Eaves LJ. Symptoms of anxiety and depression: Same genes, different environments? Arch Gen Psychiatry 1987; 44: 451-457.

14. Kendler KS, Neale MC, Kessler RC, Heath AC, Eaves LJ. Depression and generalized anxiety disorder. Same genes, (partly) different environments? Arch Gen Psychiatry 1992; 49: 716-722.

15. McGue M, Gottesman II, Rao FC. The transmission of schizophrenia under a multifactorial threshold model. Am J Hum Genet 1983; 35: 1161-1178.

16. Kringlen E. Genes and environment in mental illness. Perspectives and ideas for future research. Acta Psyciatr Scand 1993; 370 (Suppl): 79-84.

17. Wright S. Correlation and causation. J Agric Res 1921; 20: 557-585.

18. Tambs K, Harris JR, Magnus P. Sex specific causal factors and effects of common environment for symptoms of anxiety and depression in twins. Behav Genet 1995; 25: 33-44.

19. Jöreskog KG, Sörbom D. LISREL 7. A guide to the program and applications, 2nd edn. SPSS Inc, Chicago, Illinois, 1989.

20. Tambs K, Harris JR, Magnus P. Genetic and environmental contributions to the correlation between alcohol consumption and symptoms of anxiety and depression. Results from a bivariate analysis of Norwegian twin data. Behav Genet 1997; 27: 241-250.

21. Hesbacher PT, Rickels R, Morris RJ, Newman H, Rosenfeld MD. Psychiatric illness in family practice. J Clin Psychiatry 1980; 41: 6-10.

22. Eysenck HJ, Eysenck SBG. The manual for Eysenck Personality Questionnaire. Hodder \& Stoughton, London, 1975.

23. Tambs K. Transmission of symptoms of anxiety and depression in nuclear families. J Affective Disord 1991; 21: 117-126.

24. Spitzer RL, Williams JB, Gibbon M. Structured Clinical Interview for DSM-III-R. Biometrics Research Department, New York State Psychiatric Institute, New York, 1987.

25. Torgersen S. Comorbidity of major depression and anxiety disorders in twin pairs. Am J Psychiatry 1990; 147: 1199-1202.

26. Eaves LJ, Long J, Heath AC. A theory of developmental change in quantitative phenotypes applied to cognitive development. Behav Genet 1986; 16: 143-162.

27. Tambs K, Moum T. Low genetic effect and age specific family effect for symptoms of anxiety and depression in first degree relatives including step parents and twins. J Affective Disord 1993; 27: 183-195.

28. Eaves LJ, Eysenck HJ, Martin NG. Genes, Culture and Personality. An empirical approach. Academic Press, London, 1989. 